Prof. Maheshwari went on to discuss more particularly the human problems involved, particularly the weaknesses of the Indian student and of Indian bureaucracy.

\section{University of Oxford and the Robbins Report}

THE report of a Committee appointed by the Heb. domadal Council of the University of Oxford to consider points arising out of the Robbins Report recommends the appointment of a Commission to enquire into, and report on, the part which Oxford plays now and should play in the future, in the system of higher education in the United Kingdom, having special regard to its position as a national and an international University (Supplement No. 7 to the University Gazette, March 1964. Pp. I1. Oxford: The University, 1964. 6id.). In tho light of its findings, the Commission should consider: (1) whether central institutions of the University are satisfactory and effective; (2) whother the present arrangements for the appointment and functions of the Vice-Chancellor require reconsideration; (3) whether the University is adoquately equipped with its present, organization to make its proper contribution to the discussion and formulation of policy in higher education. It is also recommended that the Commission should consider the present relations betwoen the Colleges and the University in the same context, the finance, staffing and organization of research, including libraries, methods of teaching, and of selecting undergraduates, and of the selecting and supervision of postgraduate students, including the proportion of postgraduates to undergraduates to be achievod over the next fifteen years. The Hebdomadal Council has adopted the recommendations and Lord Franks has accepted the Council's invitation to serve as chairman of the Commission.

\section{Daedalus}

THE whole of the winter 1964 issue of Daedalus, the journal of the American Academy of Arts and Sciencos, is devoted to the subject of "A New Europe". Although Dr. A. King's article, "Science and Technology in the New Europe", in which he describes briefly the European institutions of science and the organization of research, international co-operation in rosearch, and oducation, science and the economy and the devolopment of sciontific policy, is that of most immediate interest to the scientist, several other articles are of general interest. Writing on "Old Nations, Now Europe", Prof. R. Aron has some interesting comments on universities; Lord Franks deals with Britain and Europo; Prof. K. D. Bracher, with problems of parliamentary democracy in Europe; Prof. R. Dahrendorf, with recent changes in the class structure in European socioties; Prof. S. M. Report discusses the changing structure and contemporary European politics; and A. Touraine, management and tho working class in Western Europe. There are throe papors dealing with education: education in the new Europe, by $\mathbf{F}$. Bowles; the European school system: problems and trends, by F. L. Carazza; and "Is Europe Facing its Educational Problems ?" by S. Hessel. Bureaucracy and democracy in the new Europe are discussed by Prof. C. Frankel, and oconomic integration in the new Europe by R. Mayno.

\section{The Incorporated Linguist}

Besides the Throlford Memorial Lecture, "Practical Grammar", delivered by Prof. A. S. C. Ross at the British Academy on November 9, The Incorporated Linguist for January 1964 (No. 1, Vol. 3) includes two articles on the language laboratory. The first, by Miss M. A. L. Sculthorp, discusses its role in adult language courses, pointing out that electronic equipment is no guarantoe that language teaching or learning becomos more effective: too many short cuts are demanded to-day and a satisfactory knowledge of a languago can only be acquired with time and hard work and constant practice.
Given the right conditions and competent staff, the language laboratory has helped to achieve better standards. In the second article, "The Language Laboratorythe Answer to Industry's Language Problem ?", Mr. C. S. W. Hocking insists that only if industries play their part and release their staff generously for intensive tuition can the language laboratory help to solve the present language problem.

\section{Careers for Young People}

The National Union of Teachers' Annual Guide to Careers for Young People, March 1964, gives a survey covering some forty occupations, each entry moreover indicating where further information can be obtained (Pp. 80. London: National Union of Teachers, 1964. 4s.). Generally, it does not include information about scientific careers, though there are entries for electricity supply, engineering training and librarianship, as well as teaching. The samo issue includes a survey by $\mathrm{K}$. M. Allsop of opportunities for those without the General Certificate of Education, and also for tho handicapped; an article by Ross Martin introducing the school-leaver to the purposes and activities of Trade Unions; a survey of books and issued aids on careers; and a guide to the provisions of the Industrial Training Act.

\section{Research and Development of the British Broadcasting Corporation}

A LECTURE, "The Challenge of Circumstances", deliverod by W. Proctor Wilson, head of the British Broadcasting Corporation Engineering Research Department, as the fifth of the second series of B.B.C. Lunch-time Lectures, gives a vivid account of research and developmont in the Corporation seen as a response to challonging circumstances over the past forty years (The Challenge of Circumstances. Pp. 16. London: British Broadcasting Corporation, 1964). Mr. Wilson brings out very eloarly the contribution of research to the expansion of the television service since 1946, including such topics as: the standards conversion involved in the choice of the 625-line standard for B.B.C.2 with the retention for many years of the 405-line standard; the development of tho 'Cablefilm' technique in 1958 for transatlantic interchange of important news items; the improvoments in television recording and the extensive research on the modified 'compatible' system of colour television specified by the National Telovision Systom Committeo, which has since been examined in comparison with the revived French $S E C A M$ and German $P A L$ systems by a special colour sub-committee of the European Broadcasting Union. Other work has provided valuable information on the effect of different kinds of terrain on radio waves in the very-high-frequency band, on the acoustical behaviour of studios, while the development of the vory-highfrequency sound service and of steroophonic broadcasting both depended on the response of the enginoering research department to the challenge of circumstances. Such research is essentially forward-looking, and Mr. Wilson insists that, if the B.B.C. is to maintain its leading place in the art and science of broadcasting, independence of thought is its greatest ally.

B.B.C. Engineering Monograph No. 51, Radiophonics in the B.B.C., by F. C. Brooker, describes the Corporation's Radiophonic Workshop, the type of work undertaken and the equipment used (Pp. 19. London: British Broadcasting Corporation, 1963. 5s.). Much of the equipment is necessarily concerned with the manipulation of tape-recordings using fairly standard equipment, but some ancillary pieces of equipment such as the Keying Unit, the Leevers-Rich Eight-track Recorder, and the Twenty. channel Mixing Console, which have been specially doveloped, are also described, as well as tho electronic gunfire effects generator, developed earlier for direct, or 'spot', effects in studios. Use of radiophonic sound has 